\title{
A Qualitative Investigation of the Dynamics and Complexity of Language Learner Beliefs through Written Protocols
}

\author{
Ursula Ritzau (Copenhagen and Zurich)
}

\begin{abstract}
During recent years, language learner beliefs have increasingly been studied through qualitative, learner-centred methods, and the development and dynamics of language learner beliefs have been brought into focus. This paper analyses the development and complexity of beliefs expressed by three university students of Danish as a foreign language in Switzerland. A qualitative method inspired by Grounded Theory is employed and proves to be fruitful for pinpointing the dynamics and complexities of the beliefs. Data are collected through written protocols in German and Danish. The data collection phase stretches over nearly a year and a half, which facilitates a detailed exploration of temporal changes in the beliefs expressed by the study participants.
\end{abstract}

\section{$1 \quad$ Introduction}

The field of language learner beliefs research has been dominated by quantitative, researchercentred approaches, but within the last decade, a number of scholars have become increasingly interested in qualitative, learner-centred approaches to learner beliefs. Examples of this relatively new approach can be found in a collection of papers edited by Kalaja/Barcelos (2003) and in a special issue of System edited by Barcelos/Kalaja (2011). In earlier studies, scholars focussed on types and content of learner beliefs, but now "the focus seems to be on how beliefs develop, fluctuate and interact with actions, emotions, identities, or affordances and how they are constructed within the micro- and macro-political contexts of learning and teaching languages" (Barcelos/Kalaja 2011: 282). Also, Barcelos/Kalaja (2011: 285) notice a move from second language to foreign language contexts within learner belief studies.

These new tendencies match my study, which investigates learner beliefs qualitatively by means of a learner-centred approach, and focusses on the dynamic nature of beliefs within a foreign language learner context. The main research question in this article is the following: How can qualitative investigations of written expressions of learner beliefs contribute to a better understanding of the dynamics and complexity of learner beliefs?

After an outline of three approaches to learner beliefs in section 2, informants and data are presented in section 3. The qualitative method used in my study is based on Grounded Theory, which is introduced and discussed in section 4. Section 5 provides an analysis of learner beliefs expressed by three students. Section 6 discusses results and method, followed by a conclusion in section 7 . 


\section{Different approaches to studying learner beliefs}

Language learner beliefs are, as several scholars have noted, difficult to define (Barcelos 2003; Mercer 2011; Peng 2011; Woods 2003). However, a pragmatic, contextual, and - as I think - also useful attempt at a definition is given by Kalaja (2003: 87):

More specifically, I proposed that beliefs or metacognitive knowledge about SLA [second language acquisition] be viewed as a property of discourse, or as views held on aspects of SLA given by a student on specific occasions of talk (or writing) and used for specific (rhetorical) purposes.

In other words, second or foreign language learner beliefs are dependent on context and on learners' intentions in different situations. This also implies that learner beliefs are dynamic and subject to contextual, situational, and temporal change. The quote furthermore acknowledges written expressions of beliefs, which is relevant to my study.

Studies of learner beliefs reflect three different approaches: the normative approach, the metacognitive approach, and the contextual approach (Barcelos 2003; Bernat/Gvozdenko 2005).

The normative approach is characterised by quantitative studies, often carried out with Likertscale questionnaires (Horwitz 1999; Cotterall 1999; Yang 1999) based on the Beliefs About Language Learning Inventory (BALLI) used in some of the first pioneering belief studies (e.g. Horwitz 1988). BALLI was developed on the basis of second and foreign language teachers' and students' statements about their own and other people's beliefs about language learning (Horwitz 1988). Horwitz (1988: 284) "decided to keep the BALLI items in the subjects' own words whenever possible", meaning here the subjects who were asked when BALLI was created. Chances are that the BALLI questionnaire is relevant to most learners, because it is after all based on students' statements. However, future language learners answering the BALLI questions do not have the chance to express beliefs in their own words. When filling out the questionnaire, learners will probably find some questions more and some questions less relevant, and the questionnaire might leave out topics that could be relevant to specific learners. Studies within the normative approach have focussed on describing and classifying types of beliefs (Barcelos 2003: 11) and less on the development of beliefs. This approach represents a static view.

Within the metacognitive approach, most often represented by Wenden (e.g. 1999; 2001), learner beliefs are studied by means of semi-structured interviews and self-reports and to some extent questionnaires, and they are concerned with the connection between beliefs and autonomous learner behaviour (Barcelos 2003). One example is Graham (2006), a study using questionnaires and semi-structured interviews to describe the influence that metacognitive knowledge has on strategy use and motivational maintenance among 16 to18-year-old foreign language students. The study concludes that students who are focussed on improving their own performance are more likely to develop self-efficacy than students who are focussed on doing better than their peers. In another study, Navarro and Thornton (2011) use a contextual approach to investigate metacognitive knowledge, thus implying some similarities between metacognitive and contextual approaches.

The contextual approach, also referred to as discursive (Kalaja 2003) or ecological (Bernat 2008), adopts ethnographic methods such as classroom observation (Barcelos 2003), and lets 
students describe and comment on learner beliefs in their own words. Within such a perspective it is plausible that students talk or write about the aspects of learner beliefs they find most important (Kalaja 2003). This contrasts with the questionnaire surveys within the normative approach, where informants answer a range of questions they might or might not find relevant. The contextual approach focusses on how beliefs develop, on how they are constructed, and on how they interact with actions and identities (Barcelos/Kalaja 2011).

Peng's (2011) study of a first year college student's beliefs about learning English as a foreign language demonstrates how beliefs develop and change over time. Over a period of seven months, Peng (2011: 314) collected data consisting of semi-structured interviews, classroom observations and learning journals. The beliefs of the student in the study change according to classroom affordances, remaining time until next exam, and occasional boredom or confusion about learning goals. Peng (2011: 322) concludes that "beliefs are fluid, contextual and emerging".

My study is predominantly contextual. It is qualitative and explorative, and I let students describe their beliefs in their own words. The contextual approach facilitates analyses of the construction of the beliefs in question and reveals beliefs as often complex and mostly dynamic. Sometimes students even express seemingly contradictory beliefs in one and the same protocol, as illustrated in section 5.

\section{$3 \quad$ Informants and data}

In this article, I present part of the data from an ongoing research project. Between September 2007 and December 2008, 49 students of Danish at the universities of Basel and Zurich, Switzerland, filled out questionnaires, participated in audio recordings and wrote protocols during their first three semesters of learning Danish. This article will focus on language learner beliefs expressed in written protocols.

Ideally, the students wrote six protocols each, i.e. two per semester. The first protocol was written in German only a couple of weeks after the first lesson, and the following five in Danish. I asked the students to write one half to one A4 page about their own expectations of and experiences with learning Danish. They were free to use the ideas and Danish phrases I provided them with or to write according to their own interests.

My method of analysis is inspired by Grounded Theory (Charmaz 2006; Corbin/Strauss 2008), though I do not follow its course of action slavishly (cf. Benson/Lor 1999). One of the most salient categories in the data is constituted by language learner beliefs, i.e. students' lay theories about foreign language learning. The beliefs the students express are interesting not only because they differ from mine, i.e. those of their teacher, but also because they are complex and dynamic and change over time. The complexity and dynamics of the expressed beliefs come to the fore because the study is qualitative and lets students choose their own focal points when writing about their language learning process, and because it is a longitudinal study with several data collection points.

\section{$4 \quad$ Method}

Grounded Theory is a qualitative method of analysis, helping the researcher build theory grounded in data (Corbin/Strauss 2008; Glaser/Strauss 1999 [1967]). This is done through 
repeated readings, codings, and categorisations of data. In this section, I present an outline of Grounded Theory before describing the qualitative method used in this study.

\subsection{An outline of Grounded Theory}

An important point when using Grounded Theory is that the researcher alternately collects data, analyses data, and collects additional data. One of the advantages of using qualitative methods is that the researcher often has the opportunity to return to the informants to ask clarifying questions or to supplement already existing data in other ways. Charmaz (2006: 14) calls this "the flexibility of qualitative research". Grounded theorists can sharpen their focus by alternating between data collection and analysis. By analysing recently collected data, the researcher gets an early insight into data and is directed towards further data collection. If a certain category is particularly interesting, he or she can close in on the category by collecting more data about it. This will likely strengthen the analysis, and a stronger analysis will again lead the researcher to supplementary data collection.

Another important point when applying Grounded Theory is the use of codings and categorisations. The first step is to read carefully through data and to structure data with codes. Charmaz (2006: 46) describes data coding in the following way: "Grounded Theory coding consists of at least two main phases: 1) an initial phase involving naming each word, line, or segment of data followed by 2) a focussed, selective phase that uses the most significant or frequent initial codes to sort, synthesize, integrate, and organize large amounts of data." Coding data word-by-word or line-by-line is time-consuming but will help the researcher to attain an analysis solidly grounded in data (Corbin/Strauss 2008).

After coding the data, the researcher can start developing categories based on the codes. Codes and categories vary in their level of abstraction, and the lower-level concepts "point to, relate to, and provide the details for the higher-level concepts" (Corbin/Strauss 2008: 52). This connection between different levels of analysis aims at ensuring that the more general, abstract categories are directly based on data. In other words, this detailed coding ensures that codes are directly extracted from data. If the researcher uses codes and categories for the analysis defined in advance, there is a substantial risk that he or she will overlook important aspects and useful categories. Qualitative analyses are often explorative and aim at developing new concepts and understandings. If qualitative researchers knew all variables and their relevance to different correlations beforehand, there would be no need for doing qualitative research (Corbin/Strauss 2008: 57).

The strong focus on data as the basis for theorising has led to discussions about the importance of existing hypotheses and theories. Kelle (2005: $\S 1)$ asks: "Can the claim to discover theoretical categories and propositions from empirical data be reconciled with the fact that researchers always have to draw on already existing theoretical concepts when analysing their data?" An analysis always reflects the researcher's academic background, theoretical stance, and thematic interest. Researchers should not neglect these perspectives, since they are dependent on them to be able to do research at all (Kelle 2005; Charmaz 2006). It is of major importance that researchers are aware of their approach and that they describe their method or methods thoroughly. 


\subsection{The qualitative method used in this study}

I investigate the development of students' learner beliefs within the limits of three semesters, and data collection took place during these three semesters. I started my analyses after data collection had been completed, as opposed to Grounded Theory guidelines. But in reading, coding and categorising the written protocols, my method is inspired by Grounded Theory.

My first step is to read through all protocols without taking notes so as to get a first impression. On the second reading, I code all protocols line-by-line; i.e. I note down my own codes for every line or sentence. My codes are more generally stated than the original statements written by the students. On the third reading, I firstly concentrate on my own lineby-line codings and specify them. Secondly, I double-check that my codings match the wordings of the students. To keep both the original data and my codings on the same piece of paper, I downsize photocopies of the written protocols to be able to write my second reading codes in the margin of each piece of paper and third reading codes underneath the downsized protocol. This helps me compare data and codes continuously. On the fourth reading of the protocols, I create categories based on the codings. I note down the most frequent and most salient codes on pieces of paper and group them according to their content. At the same time, I reread the protocols to make sure that the categories reflect what students wrote.

After developing relevant categories based on the data, I read the protocols for the fifth time to double-check for quotes that I might have overlooked but match the categories. For every student and every protocol I record relevant quotes for each category, and these are the quotes I use to illustrate my analyses in section 5 of this article. Table 1 shows how the development from data to code to category works.

\begin{tabular}{|l|l|l|l|}
\hline Reading & Coding & Example A & Example B \\
\hline $1^{\text {st }}$ & - & $\begin{array}{l}\text { "Ich will damit sagen, } \\
\text { dass ich zwar passiv viel } \\
\text { weiss, aber (unter } \\
\text { anderem aus Angst, es } \\
\text { falsch auszusprechen) } \\
\text { aktiv dieses Wissen } \\
\text { (noch) nicht anwenden } \\
\text { kann." (B016, 1.1) }\end{array}$ & $\begin{array}{l}\text { "Jeg tror at læser dansk } \\
\text { min læringsproces og min } \\
\text { ordforråd." (B006, 2.1) }\end{array}$ \\
& & $\begin{array}{l}\text { Difficult to use language } \\
\text { for fear of wrong } \\
\text { pronunciation. Great } \\
\text { passive knowledge. } \\
\text { Limited practical use. }\end{array}$ & $\begin{array}{l}\text { Reading enhances } \\
\text { vocabulary learning. }\end{array}$ \\
\hline $2^{\text {nd }}$ & $1^{\text {st }}$ & $\begin{array}{l}\text { Great passive knowledge, } \\
\text { difficult to use it actively } \\
\text { for fear of wrong } \\
\text { pronunciation. }\end{array}$ & $\begin{array}{l}\text { Reading enhances } \\
\text { vocabulary learning. }\end{array}$ \\
\hline $3^{\text {rd }}$ & & $\begin{array}{l}\text { Category: Reception } \\
\text { precedes production. }\end{array}$ & $\begin{array}{l}\text { Category: Vocabulary } \\
\text { learning. }\end{array}$ \\
\hline $4^{\text {th }}$ & $\begin{array}{l}2^{\text {nd }} \\
5^{\text {th }} \text { and following }\end{array}$ & $\begin{array}{l}\text { Double-check for } \\
\text { relevant quotes }\end{array}$ & - \\
\hline
\end{tabular}

Table 1: Examples of codings. First column shows readings, second column codings; third and fourth columns show examples of codings developed out of students' statements

The two examples illustrated in Table 1 are quite different. Example $\mathrm{A}$ is more complex and thus coded in more steps, whereas example B is simpler and needs fewer coding steps. The categories are necessarily more general than and do not include all aspects of the original 
wordings. The categories facilitate an overview and internal comparison of the data. As categories are short and general, it is necessary to keep alternating between categories and original quotes when analysing the data. For example, the category "Reception precedes production" groups example A with other relevant quotes in this category, but it does not say why reception precedes production. To find the students' reason for this statement, namely that she is afraid of pronouncing something incorrectly, it is necessary to go back to the codes or the original quote.

Developing codes and categories for each sentence in each protocol permits an overview and a detailed analysis of each single protocol. On the one hand, all protocols written by one single student can be compared over time to investigate temporal changes. On the other hand, the protocols can be analysed cross-sectionally to compare a range of students at one point in time.

\section{$5 \quad$ Dynamic and complex beliefs expressed by three students}

49 university students in Basel and Zurich, Switzerland, participated in the study, and data were collected during the first three semesters of a Danish class that I taught from September 2007 to December 2008. Materials and teaching methods in class were mainly communicatively oriented and mostly more communicative than what the students had been used to in other language classes in Switzerland. In addition to communicative tasks, however, grammar exercises and pronunciation drills were also used.

Most students are in their early twenties, and almost all speak Swiss German as their (only) first language. They all speak High German as well, some of them regarding this as a foreign language. According to their own estimates they speak three foreign languages each on average when starting their first Danish lesson. About $40 \%$ of the students speak Norwegian or Swedish, languages that are grammatically, orthographically and lexically very close to Danish. Although the students are in their first Danish class, this does not necessarily mean that they are first semester students at university.

Three students suffice to represent the greater picture of complex and dynamic beliefs expressed by the students in my study. The students B009, B013, and B020 were selected due to their different degrees of focus on beliefs and their representativeness for the overall group of students. The three students analysed here are from Basel, thus the letter "B" before their informant numbers. All data excerpts are in the original German or Danish, and my English translations of them follow in italics. My translations into English follow orthographic norms, but original quotes have not been corrected. Where I have added comments to excerpts, they are put in square brackets. The numbers in brackets after each excerpt refer to informant, semester, and protocol. For example, B009, 2.1 means 'informant B009, second semester, first protocol of the semester'. In the next three sections, analyses of the three selected students are presented individually, followed by a summary in section 5.4.

\subsection{Student B009}

Student B009 is a 23-year-old woman who speaks Swiss German as her first language and the foreign languages Swedish, English, French and Italian. She does not write much about learner beliefs, but her few statements clearly change during the three semesters. In the two 
protocols from the first semester, she is concerned with academic structure, systems, and orderliness, and her main focus is grammar:

\section{Excerpt 1}

"Ich denke dass man auf universitärem Niveau ein strukturierteres und anspruchsvolleres Lernmittel verwenden könnte (z. B. Langenscheits)." (B009, 1.1)

'I think that at university level one could use more structured and demanding teaching materials (e.g. Langenscheidts).'

\section{Excerpt 2}

"Jeg tror at det er lettere om man lærer den [grammatik] meget systematisk for at man få en ordning i hoved." (B009, 1.2)

'I think it is easier to learn it [grammar] very systematically to get orderliness in your head.'

During the second semester, B009 expresses herself in a more holistic way by not picking out one single aspect of her own language learning but rather by including all aspects as important:

\section{Excerpt 3}

"Det er vigtigt og nødvendigt at lære sig meget om alle områder av språket fordi det hør alle sammen." (B009, 2.1)

'It is important and necessary to learn a lot about all aspects of the language because they all belong together.'

In her last protocol at the end of the third semester, the student is less focussed on learningspecific aspects of language and more interested in "being around" the language:

\section{Excerpt 4}

"Det vill være bedst om jeg går til Danmark. Det er altid meget godt når man har sproget og også lifstilen omkring sig." (B009, 3.2)

'It would be the best thing to go to Denmark. It is always very good when you have the language and the lifestyle around you.'

To conclude, student B009 moves from a structure-focussed language view to a more holistic language view and then to a view that unites language and lifestyle.

\section{$5.2 \quad$ Student B013}

The next student, B013, is a 22-year-old man. His first language is Swiss German, and he also speaks French, English, and Italian. He writes extensively about learner beliefs, mostly from a structuralist perspective. During the first semester, he writes some very clear statements:

\section{Excerpt 5}

"Die korrekte Aussprache braucht die Übung im Kurs." (B013, 1.1)

'Correct pronunciation needs practice in class.'

\section{Excerpt 6}

"Das Erlernen der Vokabeln ist nur die Frage der Disziplin [...]." (B013, 1.1)

'Learning vocabulary is only a question of discipline [...].' 


\section{Excerpt 7}

"Ich versuche mit dem Übertragen von Wörter und nützlichen Sätzen in ein Vokabularheft meinen Lernprozess zusätzlich zum Unterricht, zu den Hausaufgaben zu fördern." (B013, 1.1)

'I try to boost my learning process in addition to class and homework by writing words and useful sentences in a vocabulary notebook.'

Student B013 positions himself as an ambitious student who knows exactly what it takes to learn a language in a university course. This is a typical tendency for the students, probably partly due to the fact that they have much experience with learning foreign languages. During the second semester, he is planning to do additional work and to take on responsibility for his own language acquisition:

\section{Excerpt 8}

"Jeg har også købt et bog med ordene ind (den er kun ordene vi bruger på rejsene. Det hedder 'Reisewörterbuch')." (B013, 2.1)

'I have also bought a book with words in it (they are only words used for travelling. It is called 'Reisewörterbuch').'

\section{Excerpt 9}

"Det er svært at lære ordet konsekvent, fordi man skal lære dem flere gange om uge og det bruger selvdisciplin (jeg finder sjældent tid i løbet af semester). Derfor har jeg til hensigt at gør et intensiv-programm for at lære ordet i den uge af Zwischensemester, hvor jeg arbejder for universitetet." (B013, 2.2)

'It is difficult to study words consequently, because you need to study them several times a week and that requires self-discipline (I rarely have the time during the semester). Thus I am planning to do an intensive programme to study words in the one week between the semesters when I work at university.'

Excerpts 8 and 9 show a focus on rote memorisation for vocabulary learning. Student B013 believes that it is necessary to learn vocabulary from a predefined list or book, and, as we have already heard, he thinks that discipline is a necessary requirement. This indicates a view on language learning based on repetition and reinforcement. Furthermore, the student reckons that he will be able to learn the vocabulary of the semester within a week, as long as he works intensively on the task. At the same time, though, he admits that reading can also be a rich source of new vocabulary:

\section{Excerpt 10}

"Lekture er spannendere end grammatik og hves man læser meget, hjælper det at lære ordet." (B013, 2.2)

'Reading is more exciting than grammar, and if you read a lot, it helps expand your vocabulary.'

In the last protocol from the second semester, B013 mentions communication as an important part of language learning. However, he finds that he should focus more on vocabulary and grammar before focussing on communication:

\section{Excerpt 11}

"Kommunikation er meget viktig, tro jeg og maske skal vi gøre mere for det i kurset. Men jeg ser også jeg skal at første fokussere på ordforratning og grammatik." (B013, 
'Communication is very important, I think, and maybe we should work more on that in class. But I also realize that I have to focus on vocabulary and grammar first.'

Some of the beliefs he expresses during the third semester are much like the ones already cited above:

\section{Excerpt 12}

"Jeg sygnes det vigtigste for mig nu er at forstørre aktiv ordforrådet. Heldigvis det gør delvis sammen med at læse romaner men jeg ved at man skal også lære ord derfor." $(\mathrm{B} 013,3.1)$

'I think the most important thing for me now is to expand my active vocabulary. Fortunately, this can be done by reading novels, but I know that I also have to study words.'

\section{Excerpt 13}

"Jeg synes at al beskæftigelse med dansk fremmer lærningsporcessen men hvad mig angår er det vigtig at lære ord og udtrykke." (B013, 3.1)

'I think that all engagement with Danish enhances the learning process, but, for my part, it is important to learn words and expressions.'

He is still very concerned with learning vocabulary, and he still refers to reading and rote learning. It is also interesting that the student states more general beliefs about language learning next to beliefs about what he, as an individual learner, needs. Excerpt 14 from his last protocol shows that he differentiates between reception and production:

\section{Excerpt 14}

"Det synes mig at det er ikke så svart at forstå tekster på dansk hvis man taler tysk fordi mange ting ligner hinanden. [...] Så synes det mig at dansk er en sprog som man på overfladen hurtigt forstår hvis engang man har tilgangen. Men en passiv måde af forståelse hjælper selvfølgelig ikke at undgå ortografiske eller syntaktiske fejler." $(\mathrm{B} 013,3.2)$

'It seems to me that it is not so difficult to understand Danish texts if you speak German, because many things are alike. [...] So it seems to me that Danish is a language that you can learn to understand superficially quite fast once you have access. But of course, a passive way of understanding will not help you avoid orthographic or syntactic errors.'

Understanding Danish is, according to student B013, not very difficult for German speakers. Yet understanding Danish does not mean that learners can avoid errors, something that he apparently finds important. But then, in the same protocol from the end of the third semester, student B013 writes a completely new statement which more or less contradicts what he has written about learner beliefs until then:

\section{Excerpt 15}

"Men det synes mig at et sprog først er noget mundligt. Så det vigtigste er at lærer at kommunicere." (B013, 3.2)

'But it seems to me that language is first of all something oral. So the most important thing is to learn how to communicate.'

This student clearly goes through some changes during the three semesters, especially at the end of the third semester. It is also intriguing that he seems to be quite concerned with errors 
in the last protocol, even though he also states that communication is of primary importance. He focusses on form as well as on content.

\subsection{Student B020}

The third and last student is B020, who is 23 years old. He is also a Swiss German first language speaker and furthermore knows English and French. He starts out asking for word lists in the first semester:

\section{Excerpt 16}

"Måske det er mulig at du give os ordlistene. Så vi vider hvilken ord vi skal läre." (B020, 1.2)

'Maybe you could give us some vocabulary lists. So we know which words to learn.'

This is a frequent request of the students every semester, especially when they get closer to the exam. During the second semester, student B020 still writes about learning vocabulary by heart, and he believes this learning by heart will facilitate oral production:

\section{Excerpt 17}

"Det er også nødvendigt at lære mange ord udenad, så når man kan bedre sige hvad man tænker." (B020, 2.1)

'It is also important to learn a lot of words by heart in order to be better able to say what you think.'

\section{Excerpt 18}

"Det hjælper mig også, når jeg skriver ordne på lille kort." (B020, 2.1)

'It also helps me when I write down words on small cards.'

Interestingly, for B020 rote learning and oral communication go hand in hand, and he seems to be equally concerned with both. B020 continues to write about communication in the same protocol (2.1). He sees vocabulary rote learning as a prerequisite for learning to speak, but at the same time he says that you learn speaking through speaking.

\section{Excerpt 19}

"Det er desuden særlig vigtigt at vi lærer taler dansk mundtligt." (B020, 2.1)

'Furthermore, it is particularly important that we learn to speak Danish orally.'

\section{Excerpt 20}

"Jeg kan bedst lide, når vi har opgaver i kursen, hvor vi må snakker meget. Det er godt for vi lærer snakker dansk på denne måde." (B020, 2.1)

'I prefer class tasks in which we have to talk a lot. They are good, because we learn to speak Danish that way.'

$\mathrm{He}$ is also focussed on grammar and wants to repeat all the grammar he has learned so far before moving to Copenhagen:

\section{Excerpt 21}

"Indtil derpå [når han skal på udveksling i Kbh] jeg skal lære mange ord og jeg skal repetere den hel grammatik, som vi har lært." (B020, 2.1)

'Until then [he is going to Copenhagen as an exchange student], I must learn a lot of words and repeat all the grammar that we have learned.' 
I assume that the reference to "all the grammar that we have learned" should be understood as 'all the grammar we have dealt with in the course'. There is a semantic difference between the German word lernen, meaning 'to study' or 'to work on something' (with an imperfective aspect), and the Danish and English words at leere and to learn that have a perfective aspect, which means that after learning something, you know something new, or you have acquired a new skill.

At the end of the third semester, student B020 expresses beliefs about the importance of oral communication:

\section{Excerpt 22}

"Så skal jeg øve at bedre udtale og forstå, fordi jeg tænker at de mundlige evener er noget af de vigtigste ting, når man vil lære et sprog. Men det er også klart at det er meget svært at lære det, hvis man ikke lever der, hvor sproget er talt." (B020, 3.2)

'So I must practice for a better pronunciation and comprehension, because I think that oral skills are some of the most important things when learning a language. But it is also evident that it is very hard to learn it, if you do not live where the language is spoken.'

The first part of the quote, saying that oral skills are important, looks very much like the last quote from student B013. The second part of the quote, stressing the advantages of living among speakers of the language, resembles what student B009 wrote at the end of the third semester about being in the country where the relevant language is spoken.

\subsection{Summary of expressed beliefs}

To sum up, all three students express beliefs that change over time. B009 starts out focussing on structure, systems, and orderliness, moves on to a more holistic view on language learning and ends up emphasising the connection between language and lifestyle. Her change in focus can be characterised as a change from a structuralist perspective to a more culture-focussed perspective.

The next student, B013, makes changes in the same direction, even though his statements are more complex. During the first two semesters, he is concerned with vocabulary rote learning and discipline. In protocols 2.2 and 3.1 it seems as if an internal conflict of interest is going on. B013 finds communication "very important", but he still finds that he should focus more on grammar and vocabulary than on communication. Also, he finds reading for vocabulary learning more fun than rote learning, but nevertheless he believes rote learning to be indispensable, whereas reading for vocabulary learning is not. In his last protocol, 3.2, he is simultaneously concerned about producing orthographic and syntactic errors and convinced that language is first of all about oral communication. He seems to be expressing contradictory views.

The last student, B020, also expresses complex views. He asks for a word list, states that vocabulary rote learning is necessary, and describes how he uses vocabulary cards. At the same time, he stresses the importance of oral communication and states that language is learned through using language. This complex view on language learning holds both structure-focussed and communicative perspectives. 
In the next section, I discuss possible reasons for the changes described here, and explain why qualitative, longitudinal research is advantageous when studying such changes and complexities.

\section{Discussion}

From my description of the learner beliefs expressed by students B009, B013, and B020, who are representative of the student group, it is clear that learner beliefs are not stable. They change over time, and sometimes they even vary within one and the same written protocol. It is also clear that the learner beliefs expressed by these students start out as rather structuralist and move towards a more communicative language view during the three semesters. I have not observed the opposite tendency for any student in this study. There could be several explanations for this increasing focus on communication, and I suggest the following two as plausible.

One explanation could be that the students adapt to the beliefs of the teacher over time. In a study about second language learners in Copenhagen, Denmark, Ritzau (2007) shows how the official aims of language schools correlate with and probably influence learners' beliefs. Two schools are compared, one with a particular focus on pronunciation acquisition and one with no such focus. The students attending classes at the first school find pronunciation acquisition much more difficult ( $73 \%$ of all participants find pronunciation acquisition "most difficult") than the students from the second school (only 19\% find pronunciation acquisition "most difficult") (Ritzau 2007: 77).

Navarro/Thornton (2011) maintain that beliefs are adopted from others, and they underline "the well-established role that both previous experiences and teachers can play in learner belief development" (Navarro/Thornton 2011: 295). It seems reasonable to claim, then, that the students in my study are at least partly influenced by their teacher's beliefs.

Why students adapt to the beliefs of the teacher is another interesting question. It could have to do with power relations in the classroom, where the teacher normally sets the agenda. Or it could have to do with students' increased metacognitive awareness due to explanations and discussions about pedagogical practices and experience with alternative materials and teaching methods.

A second explanation for the students' increasing focus on communication could be that many students feel more comfortable and less anxious about communicating in Danish at the end of the third semester. This could be the reason why they consider communication to be of greater importance at the end of the course than they did when first setting out to learn Danish. It is not satisfying to feel unable to master an important skill. One way to avoid this is to deem the skill in question unimportant, in this case to regard oral communication as secondary to grammar and vocabulary learning until one feels competent when communicating orally.

Even though the students' beliefs move in the same direction, they do so with diverging rates. The beliefs student B009 expresses change neatly with the semesters. The two other students, B013 and B020, show more complex developments. They both express contradictory beliefs within one and the same protocol. Mercer (2011: 341) also found her informant expressing "seemingly contradictory statements about her Spanish abilities, such as within the same interview", and argues that "it is apparent that simple cause-and-effect models of dynamics 
cannot possibly capture the complex nature and development of any changes" (Mercer 2011: $343)$.

To capture these changes and complexities, qualitative, longitudinal studies with several phases of data collection are preferable. A qualitative approach enhances the chances of obtaining learner-centred data. In this study, students were free to write whatever they wanted about their foreign language learning process. Several phases of data collection are necessary to show how beliefs change over time and to document the directions and rates of change. A longitudinal study with only two data collections, one at the beginning and one at the end of the study, would be able to show changes over time, but not how different students change their expressions of beliefs through different paths and at different rates. Although all three students described in this article change their beliefs in the same direction, student B009 changes her expressions of beliefs with every semester, whereas the beliefs described by students B013 and B020 follow a more complex path where some aspects of the beliefs change faster than others. These different paths and rates of change reveal individual differences between learners and are only observable if several phases of data collection are carried out.

\section{Conclusion}

The review of the language learner beliefs expressed by the three students presented above clearly shows that these beliefs are dynamic and complex. These findings are possible only because the study has a qualitative outline, and because it is a longitudinal study with several phases of data collection.

The learners in this study use their own words, they pick their own topic, and write about beliefs that are important to them. A quantitative questionnaire survey would not be able to capture the complexity within one protocol to the same detail when partly contradicting statements are expressed at one and the same time. A questionnaire survey might also be able to demonstrate that a student showed conflicting beliefs, but explaining how and why the beliefs expressed by one student differ at one point in time is facilitated by the use of protocols, because they provide more detailed data. Moreover, without protocols it would not be possible to describe the ambiguity of e.g. student B013 saying that all engagement with Danish increases the learning process, but that for him personally, it is more important to do vocabulary rote learning. B013 combines an overall belief about foreign language learning with a more specific belief about what he as an individual should focus on.

To conclude, a qualitative study of written expressions of language learner beliefs conducted over three semesters with six instances of data collection is indeed suitable for revealing the dynamics and complexities of the beliefs under investigation. Further studies, e.g. using open interviews or observation, are necessary to find out whether and how learner beliefs also change according to context and not only over time.

I have investigated learner beliefs in written protocols which are part of the course work, and this may influence learners' expressions of beliefs. They know that their teacher will read the protocols, and this fact might mean that they position themselves as "good students" who know what it takes to learn a foreign language. This might very well be the case with student B013, who expresses beliefs about discipline and describes how he studies by himself outside 
the classroom. Recording students when they are discussing beliefs in more informal settings would probably reveal other beliefs, since learners might wish to position themselves differently. Thus a combination of different methods and different types of data is essential to improving and refining our understandings of language learner beliefs.

\section{References}

Barcelos, Ana Maria Ferreira (2003): "Researching Beliefs About SLA: A Critical Review". In: Kalaja, Paula/Barcelos, Ana Maria Ferreira (eds.) (2003): Beliefs about SLA. New Research Approaches. Dordrecht, Kluwer Academic: 7-33.

Barcelos, Ana Maria Ferreira/Kalaja, Paula (2011): "Introduction to Beliefs about SLA revisited". System 39: 281-289.

Benson, Phil/Lor, Winnie (1999): "Conceptions of language and language learning". System 27: 459-472.

Bernat, Eva (2008): "Beyond beliefs: Psycho-cognitive, Sociocultural and Emergent Ecological Approaches to Learner Perceptions in Foreign Language Acquisition". The Asian EFL Journal 10/3: 7-27.

Bernat, Eva/Gvozdenko, Inna (2005): "Beliefs about Language Learning: Current Knowledge, Pedagogical Implications, and New Research Directions". TESL-EJ 9/1: 1-21.

Charmaz, Kathy (2006): Constructing Grounded Theory. A Practical Guide Through Qualitative Analysis. London: Sage Publications.

Corbin, Juliet/Strauss, Anselm L. ( $\left.{ }^{3} 2008\right)$ : Basics of Qualitative Research. Los Angeles: Sage Publications.

Cotterall, Sara (1999): "Key variables in language learning: what do learners believe about them?". System 27: 493-513.

Glaser, Barney G./Strauss, Anselm L. (1999 [1967]): The Discovery of Grounded Theory: Strategies for Qualitative Research. New Brunswick: Aldine Transaction.

Graham, Suzanne (2006): "A Study of Students' Metacognitive Beliefs About Foreign Language Study and Their Impact on Learning". Foreign Language Annals 39/2: 296-309.

Horwitz, Elaine K. (1988): "The Beliefs about Language Learning of Beginning University Foreign Language Students". The Modern Language Journal 72: 283-294.

Horwitz, Elaine K. (1999): "Cultural and situational influences on foreign language leaners' beliefs about language learning: a review of BALLI studies". System 27: 557-576.

Kalaja, Paula (2003): "Research on students' beliefs about SLA within a discursive approach". In: Kalaja, Paula/Barcelos, Ana Maria Ferreira (eds.) (2003): Beliefs about SLS: New Research Approaches. Dordrecht, Kluwer Academic: 87-108.

Kalaja, Paula/Barcelos, Ana Maria Ferreira (eds.) (2003): Beliefs about SLS: New Research Approaches. Dordrecht: Kluwer Academic.

Kelle, Udo (2005): "'Emergence' vs. 'Forcing' of Empirical Data? A Crucial Problem of 'Grounded Theory' Reconsidered". Forum Qualitative Sozialforschung/Forum: Qualitative Social Research 6/2. http://nbn-resolving.de/urn:nbn:de:0114-fqs0502275, accessed October 18, 2013.

Mercer, Sarah (2011): "Language learner self-concept: Complexity, continuity and change". System 39: 335-346.

Navarro, Diego/Thornton, Katherine (2011): "Investigating the relationship between belief and action in self-directed language learning". System 39: 290-301.

Peng, Jian-E (2011): "Changes in language learning beliefs during a transition to tertiary study: The mediation of classroom affordances". System 39: 314-324.

Ritzau, Ursula (2007): Almindelig fremmed dansk. En masketest-undersøgelse hos danske learnere af holdninger til dansk med accent. Copenhagen: Københavns Universitet. (= Københavnerstudier i Tosprogethed 41). 
Wenden, Anita L. (1999): "An introduction to Metacognitive Knowledge and Beliefs in Language Learning: beyond the basics". System 27: 435-441.

Wenden, Anita L. (2001): "Metacognitive knowledge in SLA: the neglected variable". In: Breen, Michael P. (ed.) (2001): Learner Contributions to Language Learning. Harlow, Longman: 44-64.

Woods, Devon (2003): "The social construction of beliefs in the language classroom". In: Kalaja, Paula/Barcelos, Ana Maria Ferreira (eds.) (2003): Beliefs about SLA. New research approaches. Dordrecht, Kluwer Academic: 201-229.

Yang, Nae-Dong (1999): "The relationship between EFL learners' beliefs and learning strategy use". System 27: 515-535. 